\title{
The Energy Value of Oatmeal and the Digestibility and Absorption of its Proteins, Fats and Calcium
}

\author{
By R. A. McCANCE AND E. M. GLASER \\ Department of Experimental Medicine, University of Cambridge
}

(Received I I May x948)

The digestibility of wheat has been studied by many people. A technical committee of the Food and Agriculture Organization of the United Nations (Committee on Calorie Conversion Factors, 1947) reviewed certain aspects of the subject, particularly the factors to be used for calculating the available energy value of foods from their content of protein, fat and carbohydrate. The members of the committee considered that pending further investigation carbohydrates should continue to be determined by difference, and for $97-100 \%$ extraction wheat multiplied by the factor $3 \cdot 78$, and that the factors 3.59 and 8.37 should be used for protein and fat respectively. They stressed that the figure for carbohydrate 'by difference' should include fibre. In making these recommendations the Committee followed the standard American practice which had been in vogue for half a century, but they carried out no experimental work themselves in support of their conclusions. McCance \& Walsham (1948) reconsidered the whole matter in the light of the English practice of estimating the available carbohydrate in foods. They found that the protein in whole wheat was almost completely digested and absorbed, and that the nitrogen found in the faeces was 'metabolic' nitrogen. They found, however, that some $42 \%$ of the fat in whole wheat was excreted in the faeces. They noted that multiplying the protein, fat and available carbohydrate in Canadian wheat by the factors $3.65,5.5$ and 4.2 respectively gave figures for the available calories which were close approximations to those obtained by the use of the bomb calorimeter. The factors and technique of Atwater, however, as recommended by the F. A. O. Committee, gave values which were too high, but which would have been better if the figure for carbohydrate by difference had not included fibre.

Very little work has been carried out on oatmeal, and it is an interesting cereal because it contains so much fat. For these reasons it was decided to investigate its digestibility.

\section{EXPERIMENTAL}

Six men took part in the experiment. Their initials, ages, heights and weights were as follows:

$\begin{array}{clcc}\text { Initials } & \text { Age } & \begin{array}{c}\text { Height } \\ (\mathbf{c m})\end{array} & \begin{array}{c}\text { Weight } \\ \text { (kg.) }\end{array} \\ \text { E. G. } & \mathbf{3 3} & \mathbf{1 8 0} & 85 \\ \text { R. M. } & \mathbf{4 8} & 180 & 58 \\ \text { M. W. } & 31 & 183 & 75 \\ \text { J. H. } & \mathbf{3 7} & 175 & \mathbf{6 8} \\ \text { L. H. } & \mathbf{2 6} & \mathbf{1 7 4} & \mathbf{6 2} \\ \text { S. H. } & \mathbf{2 0} & \mathbf{1 8 9} & \mathbf{6 4}\end{array}$


The subjects lived on oatmeal and a little bramble jelly or syrup for I I-I 2 days. The 'experimental' period lasted 7 days, and the general arrangements and chemical methods were the same as those used by McCance \& Walsham (1948). In general only distilled water was taken, and any tap water used for drinking or for the preparation of the porridge and oatcakes was measured, so that the intakes of calcium could be determined. There were two kinds of oatmeal. The composition of the two is given in

\section{Table I. The chemical composition of the oatmeals}

(Calculated on a $15 \%$ moisture basis)

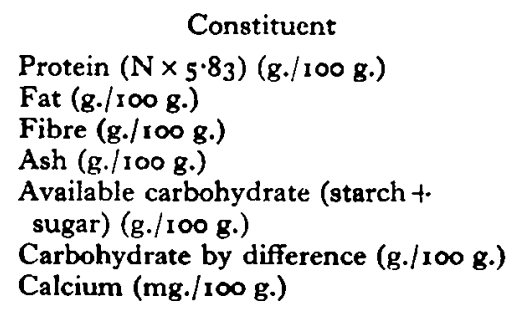

$\begin{array}{ccc}\begin{array}{c}\text { Koarsely } \\ \text { ground }\end{array} & \begin{array}{c}\text { Medium } \\ \text { ground }\end{array} & \begin{array}{c}\text { Average } \\ \text { value }\end{array} \\ \text { Pinhead, } & 8.60 & 10.15 \\ \text { II.70 } & 7.78 & 7.50 \\ 7.21 & 0.93 & 0.89 \\ 0.85 & 1.47 & 1.54 \\ 1.62 & & \\ & 58.00 & 58.00 \\ 58.00 & 67.20 & 65.90 \\ 64.50 & 50.10 & 47.50 \\ 44.90 & & \end{array}$

Table I. Since they had rather different compositions, the amounts of both kinds eaten by each person had to be recorded in order to calculate the intake of protein, fat, calcium and fibre. The subjects ate as much or as little of each of the meals as they chose, and while some took more of one than of the other, the men taken together ate the same amounts of each meal. Average figures, therefore, for the composition of the oatmeals and for the digestibility results for the six subjects have been used in assessing the available calories. Care was taken to ensure that losses in the preparation of the food and on the plates were reduced to a minimum. Some subjects took most of their food in the form of porridge and others as oatcakes made without fat. The experiment, therefore, did not provide data by which it was possible to compare the digestibility of one kind of oatmeal with another, or to compare the digestibility of oatmeal in the form of porridge with oatmeal in the form of cakes, but it gave a picture of the way in which the human intestine reacted to oatmeal, and the results may be compared with those obtained by McCance \& Walsham (1948) for wheat.

\section{RESULTS AND DISCUSSION}

\section{Energy value of absorbed nutrients}

Data about the amount of oatmeal eaten, its calorific value, and that of the total food, the dry weight and the calorific value of the faeces, and the energy value of the absorbed nutrients of the total food are given in Table 2. It will be seen that oatmeal formed $92.8-100 \%$ of the diets and, if it be assumed that the small quantities of sugar in the diets had digestibilities of $100 \%$, the available energy of the oatmeal varied from $84 \cdot$ I to 89.1 and averaged $86.6 \%$ of the calorific value of the intake. 'This is lower than the 
figures of $88 \%$ for Canadian whole wheatmeal and $89 \%$ for English whole wheatmeal which were obtained by McCance \& Walsham (1948).

Moran \& Pace (1942) suggested that the digestibility of any wheatmeal could be predicted from the percentage of fibre in it, and this conception, as it applied to wheat, was discussed by McCance \& Walsham (1948). The oatmeals used for these experiments contained some $0.9 \%$ of fibre and, according to Moran \& Pace, they should have had

Table 2. Digestibility of solid matter and available energy of the oatmeals

\begin{tabular}{|c|c|c|c|c|c|c|}
\hline \multirow[b]{3}{*}{ Subject } & \multicolumn{3}{|c|}{ Intake in 7 days' food } & \multicolumn{2}{|c|}{ Output in 7 days' faeces } & \multirow[b]{3}{*}{$\begin{array}{c}\text { Available energy } \\
\text { of oatmeal } \\
(\%)\end{array}$} \\
\hline & \multirow[b]{2}{*}{$\begin{array}{l}\text { Oatmeal, } \\
\text { dry weight } \\
\text { (g.) }\end{array}$} & \multicolumn{2}{|c|}{ Calories } & \multirow[b]{2}{*}{$\begin{array}{l}\text { Dry } \\
\text { weight } \\
\text { (g.) }\end{array}$} & \multirow[b]{2}{*}{$\begin{array}{c}\text { Calories } \\
\text { (Cal.) }\end{array}$} & \\
\hline & & $\begin{array}{l}\text { Total } \\
\text { (Cal.) }\end{array}$ & $\begin{array}{c}\text { Percentage } \\
\text { from oatmeal }\end{array}$ & & & \\
\hline R. M. & 4607 & 21,625 & 100.0 & $55^{\circ}$ & 3200 & $85 \cdot 2$ \\
\hline E. G. & 5505 & 25,200 & $95 \cdot 1$ & 518 & 2865 & 88.0 \\
\hline M. W. & 4795 & 22,710 & $99 \cdot \mathrm{I}$ & 571 & 3160 & 86.0 \\
\hline J. H. & 5323 & 26,000 & $96 \cdot I$ & 571 & 3235 & $87 \cdot 1$ \\
\hline L. $\mathrm{H}$. & 2787 & 14,100 & $92 \cdot 8$ & 393 & 2085 & $84 \cdot 1$ \\
\hline \multirow[t]{2}{*}{ S. H. } & 3960 & 19,190 & $96 \cdot 9$ & 355 & 2020 & $89 \cdot 1$ \\
\hline & & & & & Average & erage \\
\hline
\end{tabular}

a digestibility of $92 \%$. McCance \& Walsham found that wheatmeals with $0.9 \%$ of fibre had digestibilities of about $94 \%$. Subjects E.G. and R.M. have taken part in both wheatmeal (McCance \& Walsham, 1948) and the present oatmeal experiments, and when their results were compared it was found that the proportion of the calorie value of the whole wheat and oatmeal which was absorbed was very similar, although the former contained more than twice the amount of 'fibre'. It is evident, therefore, that the prediction of Moran \& Pace cannot be taken to apply to oatmeal without modification, and that oatmeal is not so well digested as wheat.

Digestibility of fibre

Table 3 shows the amounts of fibre in the food and faeces, and the percentage of it which disappeared in its passage through the alimentary canal. It will be seen that the substance or mixture of substances which were estimated as 'fibre' in oatmeal passed

Table 3. The digestibility of the fibre in the oatmeals

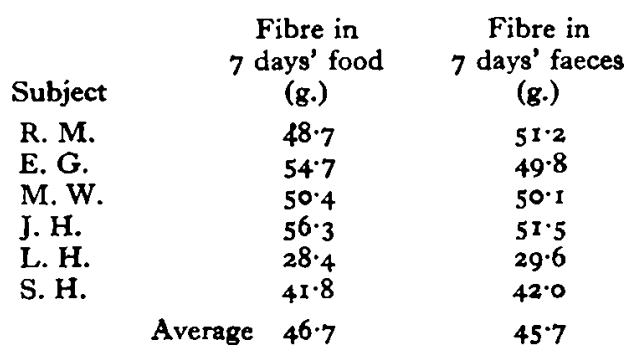

through the gut almost without change. Within the limits of experimental error in fact the digestibility of oatmeal fibre was nil. This resistance to intestinal and bacterial disintegration is greater than that of wheat fibre. McCance \& Walsham (1948) found 
digestibilities of $2 \mathrm{I}-28 \%$ for the fibre in Canadian wheatmeal and $17-25 \%$ for the fibre in English meal. Macrae, Hutchinson, Irwin, Bacon \& McDougall (1942) found digestibilities of $10-14 \%$ for the fibre in wholemeal wheat and flour. Rubner (1915, 1917) has studied this problem extensively, but it is difficult to compare his figures with the present ones, for his analytical methods were not the same. Further information may be found in the review of the subject by McCance \& Lawrence (1929). It would appear that the fibre in oatmeal might be used as a reference substance to indicate the rate and site of absorption of other substances taken with it.

\section{The digestibility of protein}

Table 4 shows the amount of nitrogen in the food and faeces, and its digestibility. The last varied from 64.9 to $81 \cdot 0$ and averaged $69 \cdot 6 \%$, a figure which is considerably lower than the tests on wheat would have led one to expect. Recent work on man

\begin{tabular}{|c|c|c|c|}
\hline Subject & $\begin{array}{c}\text { Nitrogen in } \\
7 \text { days' food } \\
\text { (g.) }\end{array}$ & $\begin{array}{c}\text { Nitrogen in } \\
7 \text { days' faeces } \\
\text { (g.) }\end{array}$ & $\begin{array}{l}\text { Percentage } \\
\text { digestibility }\end{array}$ \\
\hline R. M. & $101 \cdot 0$ & $32 \cdot 4$ & 67.9 \\
\hline E. G. & $102 \cdot 0$ & $35^{\circ} \mathrm{O}$ & $65 \cdot 7$ \\
\hline M. W. & $101 \cdot 0$ & $35 \cdot 5$ & $64 \cdot 9$ \\
\hline J. H. & 113.0 & $30 \cdot 8$ & $72 \cdot 8$ \\
\hline L. H. & $63 \cdot 2$ & $22 \cdot 0$ & $65 \cdot 2$ \\
\hline \multirow{2}{*}{ S. H. } & $83 \cdot 8$ & 15.9 & $81 \cdot 0$ \\
\hline & & & $69 \cdot 6$ \\
\hline
\end{tabular}

(cf. McCance \& Walsham, I948) has suggested that the true digestibility of wheat protein must be nearly $100 \%$, and that the apparent digestibility rises and falls with the percentage of protein in the grain. Unless, therefore, the cereals have similar amounts of protein in them the digestibility of these proteins cannot properly be compared. McCance \& Walsham (1948) found the digestibility of protein in English wheat, which contained $\mathrm{r} \cdot 49 \%$ of nitrogen, to average $74.2 \%$, and the figures for subjects E.G. and R.M. were 66.2 and $73.8 \%$ respectively. The oatmeals used for the present experiments contained higher percentages of nitrogen than the English wheat, and yet the apparent digestibility of this nitrogen was lower. The average, which has already been given, was $6.6 \%$, and the figures for E.G. and R.M. were 65.7 and 67.9 . If one takcs into account the additional fact that the oatmeals contained much less 'fibre' than the wheat and that the presence of fibre decreases the apparent digestibility of a cereal protein, one must conclude that oatmeal protein has a lower apparent digestibility than wheat protein, but the present experiments do not enable any suggestions to be made about the true digestibility of oatmeal protein. In spite of its poor apparent digestibility oatmeal protein may still have a true digestibility of nearly $100 \%$.

\section{The digestibility of fat}

Table 5 shows the intake of fat, the output and percentage of fat in the faeces and the digestibility of the fat in the oatmeal. It will be seen that the food supplied daily $34-67 \mathrm{~g}$. of fat but this was not well digested, for the dry faeces contained about $24.7 \%$ 
of fat, and the digestibility of the fat varied from 62.5 to $77 \cdot 6$. This is higher than the apparent digestibility of wheat fat, which was found by McCance \& Walsham (1948) to be $54-62 \%$, but it is much lower than the accepted figures for the digestibility of most dietary fats. Atwater recommended a coefficient of digestibility of 0.9 for the fat of whole wheat and other cereals and 0.95 for animal fats (Committee on Calorie Conversion Factors, 1947).

Table 5. The digestibility of the fat in the oatmeals

\begin{tabular}{|c|c|c|c|}
\hline Subject & $\begin{array}{c}\text { Fat in } \\
7 \text { days' food } \\
\text { (g.) }\end{array}$ & $\begin{array}{c}\text { Fat in } \\
7 \text { days' faeces } \\
\text { (g.) }\end{array}$ & $\begin{array}{l}\text { Percentage } \\
\text { digestibility }\end{array}$ \\
\hline R. M. & 403 & 142 & 64.8 \\
\hline E. G. & 456 & 129 & $71 \cdot 7$ \\
\hline M. W. & 422 & 147 & $65 \cdot 2$ \\
\hline J. H. & 469 & 154 & $67 \cdot 2$ \\
\hline L. H. & 240 & 90 & $62 \cdot 5$ \\
\hline S. H. & 352 & 79 & $77 \cdot 6$ \\
\hline \multicolumn{3}{|c|}{ Average } & $68 \cdot 2$ \\
\hline
\end{tabular}

It might have been argued that the low figures found by McCance \& Walsham for the digestibility of wheat fat were due to bacterial synthesis of some fat in the gut, for wheat contains so little fat that the synthesis of even a small quantity of fat in the bowel would appreciably affect the apparent digestibility. This argument, however, can hardly be applied to oatmeal because the quantities of fat involved are so much larger, and it must be concluded that the fats in cereals are not nearly so well digested and absorbed as people have supposed. This may be of considerable importance in calculating the fat likely to be absorbed from high-cereal, low-fat diets.

\section{The absorption of calcium}

The intake of calcium in the oatmeal and the output of this element in the faeces are shown in Table 6. It will be seen that the faeces of each subject contained more calcium than his food. This was due to the calcium in the digestive juices being trapped in the

Table 6. The intake and output of the calcium of the oatmeals

\begin{tabular}{|c|c|c|c|}
\hline Subject & fron & $\begin{array}{l}\text { Intake } \\
\text { all sources } \\
\text { (g.) }\end{array}$ & $\begin{array}{c}\text { Faecal outpu } \\
\cdot(\mathrm{g} .)\end{array}$ \\
\hline \multirow{6}{*}{$\begin{array}{l}\text { R. M. } \\
\text { E. G. } \\
\text { M. W. } \\
\text { J. H. } \\
\text { L. H. } \\
\text { S. H. }\end{array}$} & & $\begin{array}{l}5 \cdot 12 \\
4 \cdot 85\end{array}$ & $\begin{array}{l}6.62 \\
6.90\end{array}$ \\
\hline & & 3.51 & 7.03 \\
\hline & & 4.21 & 7.04 \\
\hline & & $1 \cdot 41$ & $3 \cdot 84$ \\
\hline & & $2 \cdot 37$ & 3.18 \\
\hline & Average & 3.58 & 5.77 \\
\hline
\end{tabular}

intestine by the phytic acid in the oatmeal, and the figures are reminiscent of those obtained by McCance \& Walsham ( 1948 ) in their study of wheat. All the subjects were in negative calcium balance, but it is impossible to make any exact computation of its 
magnitude without knowing the amounts lost in the urine. R.M. had an attack of cramps and tetany towards the close of the experiment which was an experience similar to the one he had after living on whole-wheat bread for 3 weeks (McCance \& Walsham, 1948). It would be very interesting to know what would have happened to the calcium balances of these men if they had continued to eat little else but oatmeal for some months.

\section{The assessment of calories in oatmeal}

The figures for the chemical composition of the oatmeals have been given in Table 1 , and the values for calories obtained by bomb calorimeter and by computation may be seen in Table 7. The total calories by bomb came to $399 \mathrm{Cal} / 100 \mathrm{~g}$. of meal, $27 \mathrm{Cal}$. higher than the figure obtained by multiplying the protein, fat and available carbo-

Table 7. The assessment of calories in oatmeal

(Calculated on a $15 \%$ moisture basis)

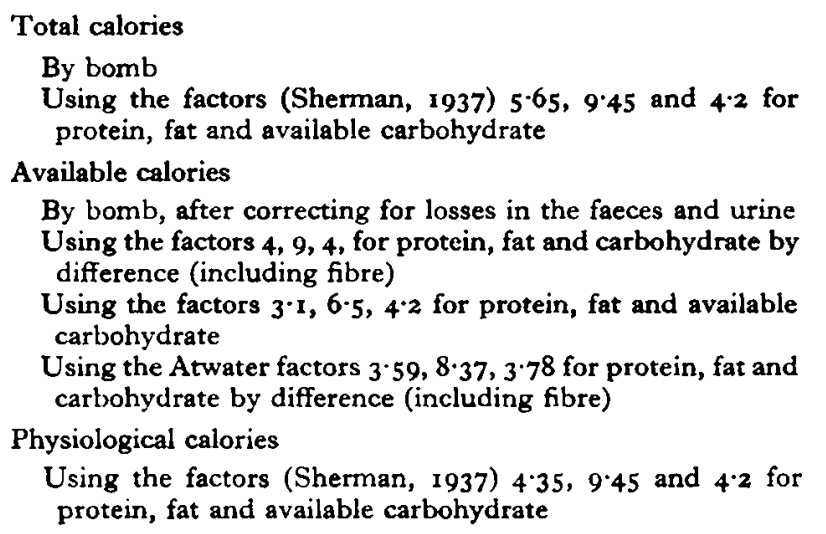

Cal./100 g.

399

372

334

37 I

324

$34^{8}$

359

hydrate by $5.65,9.45$ and 4.2 respectively (Sherman, 1937 ). This difference was due to the calories derived from unavailable pentosans and fibre being included in the figure of 399 and, if one assumes that I $\mathrm{g}$. of these unavailable carbohydrates had a calorific value of 4.2 Cal., it may be supposed that $100 \mathrm{~g}$. of oatmeal contained about $6 \mathrm{~g}$. of them.

The available calories determined by bomb after correcting for losses in the faeces and urine (Sherman, 1937) amounted to $334 \mathrm{Cal} / \mathrm{r} 100 \mathrm{~g}$. of oatmeal. The general factors 4,9 and 4 applied to the protein, fat and carbohydrate, determined by difference, produced a figure of $37 \mathrm{I}$ which is considerably higher than the value of 334, but this was to be expected (McCance, Widdowson, Moran, Pringle \& Macrae, 1945; McCance \& Walsham, I948; Committee on Calorie Conversion Factors, 1947). The figure 324 was obtained by applying the factors for the protein and fat derived from the digestibility experiments during the present study and by assuming that all the available carbohydrate would be absorbed (McCance \& Walsham, 1948). The factors recommended by Atwater for cereals gave a value of 348 . These factors, therefore, gave a figure which was a little too high. The factors (Sherman, 1937) $4.35,9.45$ and 4.2 for protein, 
fat and available carbohydrate respectively gave a figure of 359 for the physiological calories in oatmeal. This figure makes no allowance for digestibility but would be the one to be preferred by McCance \& Widdowson (1946) for use in food tables.

As with wheat (McCance \& Walsham, 1948), Atwater's cereal factors gave a figure which was appreciably higher than the bomb data. The factors would have given a better approximation if carbohydrate 'by difference' had not included 'fibre', but the committee of the Food and Agriculture Organization specifically recommended that it should. The nearest approximation to the bomb data was given by using the factors $3 \cdot 1,6.5$ and 4.2 for protein, fat and available carbohydrate. It is suggested that these figures be adopted for oatmeal, and that, if general factors for cereals are desired, $3.5,6.5$ and 4.2 should be taken for protein, fat and available carbohydrate. 'The 3.5 may be a little generous for the protein in oatmeal and 6.5 for the fat in wheat, but some allowance is made thereby for the limited number of calories which may be derived from unavailable carbohydrate and the figures give good approximations to the bomb data for wheat and oats- $329 \mathrm{Cal} . / 100 \mathrm{~g}$. in the present instance.

\section{SUMMARY}

I. Six men carried out metabolism experiments with oatmeal which provided $92 \cdot 9-$ $100 \%$ of the calories in the diets.

2. The energy value of the nutrients absorbed from the oatmeal averaged $86.6 \%$ of the intake. This figure is lower than the one obtained for wheat (McCance \& Walsham, 1948).

3. The fibre did not seem to undergo any digestion or absorption.

4. The apparent digestibility of the protein in the oatmeal was $69.6 \%$ and would certainly have varied with the amount of protein in the oatmeal. The true digestibility was undoubtedly higher, but the experiments gave no indication of how much higher.

5. The digestibility of the fat averaged only $68 \cdot 2 \%$.

6. All the subjects were in negative calcium balance during these experiments, and one of them had a severe attack of tetany at the close.

7. The protein and fibre in oatmeal were not so well digested as in wheat, but the fat was rather better digested.

8. The procedures and factors for assessing the available and other calories in oatmeal are discussed and recommendations made about the best ones to use.

The authors are indebted to Dr T. Moran and Mr R. H. Carter of the Cereals Research Station at St Albans and to Miss C. M. Walsham for their kindness and help over supplies and technique. The oatmeal was milled by Messrs R. and A. Hannay Ltd., Stranraer. Mr C. J. L. Baker was responsible for the calorie determinations.

\section{REFERENCES}

Committee on Calorie Conversion Factors and Food Composition Tables, Convened by the Nutrition Division of the Food and Agriculture Organization of the United Nations (1947). Energy-Yielding Components of Food and Computation of Calorie Values. Washington: Food and Agriculture Organization of the United Nations.

McCance, R. M. \& Lawrence, R. D. (1929). Spec. Rep. Ser. med. Res. Coun., Lond., no. 135. 
McCance, R. A. \& Walsham, C. M. (1948). Brit. F. Nutrit. 2, 26.

McCance, R. A., Widdowson, E. M., Moran, T., Pringle, W J. S. \& Macrae, T. F. (1945). Biochem. $\mathcal{F}$. 39, 213 .

McCance, R. A. \& Widdowson, E. M. (1946). Spec. Rep. Ser. med. Res. Coun., Lond., no. 235, 2nd ed. Macrae, T. F., Hutchinson, J. C. D., Irwin, J. O., Bacon, J. S. D. \& McDougall, E. I. (1942). J. Hyg., Camb., 42, 423.

Moran, 'T. \& Pace, J. (1942). Nature, Lond., 150, 224.

Rubner, M. (1915). Arch. Anat. Physiol., Lpz., Physiol. p. 135.

Rubner, M. (I g17). Arch. Anat. Physiol., Lpz., Physiol. p. 245.

Sherman, H. C. (1937). The Chemistry of Food and Nutrition, 5th ed. New York: The Macmillan Co.

\section{Ascorbic Acid and Epithelial Regeneration}

By NANCY M. GALLOWAY, University College, Dundee, University of St Andrews

R. C. GARRY, Institute of Physiology, University of Glasgow

AND A. D. HITCHIN, School of Dentistry, Dundee, University of St Andrews

(Received I9 May 1948)

In animals suffering from deficiency of ascorbic acid the healing of incised wounds is delayed and imperfect because of the defective formation of collagen (Wolbach \& Howe, 1926; Crandon, Lund \& Dill, 1940; Hunt, 1941; Bourne, 1944).

But not all wounds are incised; there may be also loss of epithelium. So far no attention seems to have been paid to the effect of lack of ascorbic acid on epithelial repair.

\section{EXPERIMENTAL}

\section{Animals}

Most of the work was carried out on guinea-pigs. To find if consumption of an excess of ascorbic acid affected wound healing, rats were also used, although rats cannot be made to suffer from deficiency of ascorbic acid.

\section{Diets}

All animals received a basal diet of rat-cake nuts (Thomson, 1936). These nuts are free from ascorbic acid. Control guinea-pigs received daily $5 \mathrm{mg}$. of ascorbic acid in solution by mouth. This dose kept the guinea-pigs in perfect health; immature animals grew normally on this diet. 'The guinea-pigs deficient in ascorbic acid received $0.5 \mathrm{mg}$. ascorbic acid every and day. In these animals signs of deficiency appeared in about 14 days, but the dose was sufficient to keep them alive and fit to bear the operative interference.

\section{Wounding}

Removal of corneal epithelium. This operation was carried out only in guinea-pigs. Ether anaesthesia was used and Holocaine (Bayer Products Ltd.) dropped into the conjunctival sac. A $2 \%$ solution of fluorescein was also placed in the conjunctival sac 